\title{
Effect of Embryo Transfer Seven Days after Artificial Insemination with Sexed and Conventional Semen from Superovulated Cattle
}

\author{
Enkhbolor Barsuren ${ }^{2, \#}$, Sang Hwan Kim ${ }^{1, \#}$, Ho-Jun Lee ${ }^{1}$ and Jong Taek Yoon ${ }^{1,3, *}$ \\ ${ }^{1}$ Institute of Genetic Engineering, Hankyong National University, Anseong 17579, Korea \\ ${ }^{2}$ Major in the Animal Biotechnology, The Graduate School of Biology \& Information Technology, Hankyong National \\ University, Anseong 17579, Korea \\ ${ }^{3}$ Department of Animal Life Science, Hankyong National University, Anseong 17579, Korea
}

\section{Received May 26, 2019}

Revised June 11, 2019

Accepted June 25, 2019

\section{*Correspondence}

Jong Taek Yoon

Department of Animal Life Science, Hankyong

National University, 327 Jungang-ro,

Anseong 17579, Korea

Tel: +82-31-670-5094

Fax: +82-31-675-8265

E-mail: jtyoon@hknu.ac.kr

ORCID

https://orcid.org/0000-0002-9408-8239

"The authors contributed equally to this work.
ABSTRACT Sexed sperm can contribute to increase the profitability of the cow industry through the production of offspring of the craved sex, such as males for meat or females for dairy production. Therefore, the utilization of sexed sperms plays a very important role in the production of offspring of superior cattle. In this study, we examined the pregnancy rates and calves sexing proportion of male and female calves produced using Al, both performed using sexed and conventional sperm. In the result, the conception rates after ET were $73.3 \%$ (33/45) sexed semen and 52\% (55/104) conventional semen. Thus, the sex ratio for sexed-semen inseminations was $70 \%$ (21/30) females for singleton births within a 272 to 292 day gestation interval. The sex ratio for conventional semen was $61 \%$ (34/56) females for births. As a result, it is suggested that the use of sex classification sperm will play a very important role in the offspring production of Korean bovine.

Keywords: bovine, embryo, gestation, offspring, sexed sperm

\section{INTRODUCTION}

Sexed sperm is now widely used in cattle breeding to enhance industrial competitiveness and achieve high female fertility (Seidel, 2003; Rath et al., 2008).

The production rates of fresh viable embryos using conventional semen with the sexed methodologies of embryo transfer (ET) and superovulation do not yield acceptable results. Accordingly, it is needful to use a greater number of doses of semen per superovulated cow to obtain high embryo production, including a change in the artificial insemination (AI) time (Baruselli et al., 2006; Dell'Aqua Jr et al., 2006). Sperm sexing does not affect the sperm's ability to fertilize the oocytes, but it can affect the ability of embryos to develop normally after fertilization (Morton et al., 2007; Underwood et al., 2010).

Sexed sperm can contribute to increase the profitability of the cow industry through the production of offspring of the craved sex, such as males for meat or females for dairy production. Other applications would allow cattle breeders and AI sperm companies to test elite bulls on small numbers of females (Hossein-Zadeh et al., 2010).

Therefore, advancement of reproductive biotechnologies seems to have reached a limit, and its implementation relies on basic knowledge of the embryos and biology of gametes. The limiting factors provide an opportunity 
for unification of epigenetics knowledge. Embryos and gametes must pass through a broad epigenetic reprogramming process to be able to be fertilized and form a viable embryo (Reik, 2001; 2007).

ET in cattle can be an important tool for genetic modification and can improve pregnancy rates compared with AI when fertility is low, such as during heat stress or in repeat breeder cows (Hansen, 2004; 2007; Block et al., 2010; Stewart et al., 2011). In addition, many reports demonstrating a reduction in the number of transferable in vivo embryos when sexed semen is used, the quality grades of embryos are included in the analysis in only a few reports. A compromised fertilization rate in cows inseminated with sexed semen is obvious, but with respect to the proportion of quality grade 1 embryos, either no difference or a decrease has been reported (Sá Filho et al., 2008; Hayakawa et al., 2009; Peippoet al., 2009; Larson et al., 2010). AI using sexed semen (sexed AI) has a pregnancy rate lower than that using conventional semen (Carvalho et al., 2010; DeJarnette et al., 2011).

We bought a "Whole-mom" from the Nuri Science Co., Ltd company. Sperm sexed by "Whole-mom", with purities of over $80 \%$ of X-bearing sperm, can be used for AI with subsequent transfer of the embryos produced. Therefore, the objective of this study was to evaluate the pregnancy rates and calves sexing proportion of male and female calves produced using AI, both performed using sexed and conventional semen.

\section{MATERIALS AND METHODS}

\section{Animals}

The study was carried out spring to autumn season (March to october) on 149 Hanwoo bred on a farm located in Southern Korea. The Hanwoo were housed in free stall facilities, fed complete rations, and allowed free access to mineralized salt and water. The Hanwoo were included in the study based on a clinical examination including good ovary and normal uterus, were selected.

\section{Estrus synchronization}

For the donor cows, four days after the insertion of Progesterone Releasing Intravaginal Device (CIDR; Hamilton, New Zealand) into the vagina of cows using a CIDR injector, estrus cycle was induced by the administration of FSH (Kyoritsu seiyakucoporation, Japan) for 4 days with an interval of $12 \mathrm{hr}$ between each FSH injection. PGF $_{2 \alpha}$ (Zoetic, Belgium) was administered 2 days after FSH injection. Three days later, CIDR was removed. AI was carried out using sexed and conventional semen, 3 times with a $12 \mathrm{hr}$ interval between the procedures, after the injection of GnRH (250 $\mu \mathrm{g}$, DongBang, Korea).

\section{Sexing of semen (sperm) and Al}

In all superovulated donors, inseminations were initiated 12 hours after the onset of standing estrus. All six batches of frozen-semen used came in $0.5 \mathrm{~mL}$ straws. For experiments cattle were used as embryo donors and were treated in a same manner (Table 1) in 2016. Semen were

Table 1. Procedures for embryo recovery of donor and embryo transfer to recipients

\begin{tabular}{|c|c|c|c|c|}
\hline \multirow{2}{*}{$\begin{array}{c}\text { Treatment } \\
\text { day }\end{array}$} & \multicolumn{2}{|c|}{ Donors } & \multicolumn{2}{|c|}{ Recipients } \\
\hline & AM & PM & $\mathrm{AM}$ & PM \\
\hline \multirow[t]{3}{*}{0} & P4 device insertion & - & P4 device insertion & - \\
\hline & 50 mg P4 & & 50 mg P4 & \\
\hline & 1 mg E2 & & $1 \mathrm{~g} \mathrm{E} 2$ & \\
\hline 4 & $6 \mathrm{mg} \mathrm{FSH}$ & $6 \mathrm{mg} \mathrm{FSH}$ & - & - \\
\hline 5 & $5 \mathrm{mg} \mathrm{FSH}$ & $5 \mathrm{mg} \mathrm{FSH}$ & - & - \\
\hline \multirow[t]{2}{*}{6} & $4 \mathrm{mg}$ FSH & $4 \mathrm{mg} \mathrm{FSH}$ & 0.625 mg PGF2 $\alpha$ (Croprostenol) & - \\
\hline & 30 mg PGF2 $\alpha$ (Dinoprost) & 15 mg PGF2 $\alpha$ (Dinoprost) & & \\
\hline \multirow[t]{2}{*}{7} & P4 device removal & $3 \mathrm{mg} \mathrm{FSH}$ & P4 device removal & - \\
\hline & $3 \mathrm{mg} \mathrm{FSH}$ & & & \\
\hline \multirow[t]{2}{*}{8} & Estrus & Al & Estrus & $250 \mu \mathrm{g} \mathrm{GnRH}$ \\
\hline & & $100 \mu \mathrm{g} \mathrm{GnRH}$ & & \\
\hline 9 & $\mathrm{Al}$ & $\mathrm{Al}$ & - & - \\
\hline 15 & \multicolumn{2}{|c|}{ Embryo Recovery } & \multicolumn{2}{|c|}{ Embryo Transfer } \\
\hline
\end{tabular}


thawed by first holding them in the air, at room temperature $\left(24^{\circ} \mathrm{C}\right)$ for $5 \mathrm{~s}$ and then plunging them into a water bath at $37^{\circ} \mathrm{C}$ for $20 \mathrm{~s}$. In this experiment, sexed semen was mixed with "Whole mom (Nuri Science Co., Ltd company)" in a water bath at $37^{\circ} \mathrm{C}$ for 20 minutes. The sexed and conventional semen was deposited in the body of the uterus.

\section{Embryo collection and evaluation}

Embryos were collected 7 days after inseminations by transcervical uterine flushing using a Dulbecco's phosphate-buffered saline (D-PBS) 2\% FBS supplemented media. After collection, embryo morphology was assessed under a stereomicroscope (60 magnification), and recovered embryos were evaluated according to the International Embryo Technology Society (IETS) classification guidelines for the developmental stage ( $4=$ compact morula, $5=$ =arly blastocyst, $6=$ blastocyst, $7=$ expanded blas tocyst, $8=$ hatched blastocyst, and $9=$ expanding hatched blastocyst) and quality (grades $1-2$ ) by experienced embryo transfer practitioners.

\section{Transfer of embryos}

Selection of recipients was performed immediately before ET Recipient acceptance focused on time elapsed from standing estrus (6.5 to 7.5 days), quality of corpus luteum (CL) and serum levels of P4 on Day 0 and Day 7, as previously reported in Hidalgo et al (Hidalgo et al., 2004). Embryos were nonsurgical transferred to the uterine horn ipsilateral to the CL, under epidural anesthesia $(4 \mathrm{~mL}$, 2\% lidocaine chlorhydrate, Laboratorios Ovejero, Leon, Spain). Grades 1-2 quality fresh embryos were washed twice in embryo D-PBS medium with 20\% FBS and then loaded into straws in the same medium. Collected Day 7 embryos were transferred to synchronous mixed breed recipient cows. A total of 149 cows were used as recipients.

Table 2. Calving rate after ET derived from sexed or conventional semen in Hanwoo

\begin{tabular}{lccc}
\hline $\begin{array}{c}\text { Semen } \\
\text { type* }\end{array}$ & $\begin{array}{c}\text { No. of } \\
\text { transferred } \\
\text { cows }\end{array}$ & $\begin{array}{c}\text { No. of } \\
\text { pregnant } \\
\text { Cows (\%) }\end{array}$ & $\begin{array}{c}\text { Calving } \\
\text { rate (\%) }\end{array}$ \\
\hline Sexed & 45 & $33(73.3)$ & $30(66.7)$ \\
Conventional & 104 & $55(52.8)$ & $55(52.8)$ \\
\hline
\end{tabular}

*Sexed semen is mean used 'whole mom' semen and conventional is control group.

\section{Pregnancy diagnosis, fetal sex and calving}

Two months after embryo transfer, a rectal palpation was performed to evaluate pregnancy. Fetal sex was judged by confirming the birth fetus.

\section{RESULTS AND DISCUSSION}

In the result, the conception rates after ET were $73.3 \%$ (33/45) sexed semen and 52\% (55/104) conventional semen (Table 2). And the sex ratio for sexed-semen inseminations was $70 \%$ (21/30) females for singleton births within a 272 to 292 day gestation interval. On the other hands, sex ratio for conventional semen was $61 \%(34 / 56)$ females for births (Table 3).

The use of X-sexed sperm, already widely employed for AI in dairy cattle (Norman et al., 2010), has the potential to alter the structure of the dairy industry by increasing the replacement heifer supply, creating opportunities for using a proportion of the dairy herd for producing beef animals, and improving the rate of genetic selection (De Vries and Feleke, 2008). Use of X-sexed sperm in ET programs represents another use of this technology.

Conception rates after ET achievable with sexed semen vary significantly across studies, which emphasizes the influence of on farm factors. Conception rates after ET can be affected by parity, body condition, sire selection, and accuracy of estrus detection (Seidel and Schenk, 2008). In this study, we investigated the farmers who are breeding through the ET technique and found that the pregnancy rate of sexing sperm was not lower than that of conventional sperm. These results suggest that the sexed semen by Whole-mom has no effect on the decrease of fertilization rate and the decrease of pregnancy rate. On the other hand, pregnancy rate was rather $73.3 \%$ in the case of sexed semen, which appeared higher than $52.8 \%$ of ordinary semen, which is similar to the research results of

Table 3. Effect of sexed and conventional semen on calving and gestation periods

\begin{tabular}{llrcc}
\hline $\begin{array}{c}\text { Semen } \\
\text { type* }\end{array}$ & \multicolumn{1}{c}{$\begin{array}{c}\text { Calf } \\
\text { sex }\end{array}$} & $\begin{array}{c}\text { No. born } \\
\text { (\%) }\end{array}$ & $\begin{array}{c}\text { Gestation period } \\
\text { (days } \pm \text { SE) }\end{array}$ & $\begin{array}{c}\text { No. } \\
\text { Abortion (\%) }\end{array}$ \\
\hline Sexed & Female & $21(70.0)$ & $280.4 \pm 4.8$ & $3(0.1)$ \\
& Male & $9(30.0)$ & $279.4 \pm 5.4$ & \\
Conventional & Female & $34(61.0)$ & $276.6 \pm 7.7$ & $0(0.0)$ \\
& Male & $22(39.0)$ & $280.3 \pm 6.2$ & \\
\hline
\end{tabular}

* Sexed semen is mean used 'whole mom' semen and conventional is control group. 
Seidel and Schenk considered to be due to the environmental condition and nutritional condition of each cows.

The sex ratio for conventional semen was in accordance with most trials, which achieve approximately 50 to $52 \%$ males (Tubman et al., 2004; DeJarnette et al., 2009). However, Norman et al. (2010) observed only $48.5 \%$ single males born to heifer dams. According to Nuri Science, in the case of the 'whole mom' used in this experiment, Ysperm agglutination protein is used to inhibit the fertilization of Y-sperm to induce the regulation of sex, in this case, about $70 \%$ was regulated.

The results for gestation length were in accordance with several studies reporting that gestation length in dairy cattle is affected by parity, season, sire, the incidence of twins, and calf sex (Fisher and Williams, 1978; DeJarnette et al., 2009; Norman et al., 2009). Apart from the effect on calf sex, semen sexing did not significantly attenuate or prolong gestation length, in agreement with Tubman et al. (2004).

In conclusion, according to this study, when a sexcontrolled sperm was compared with a normal sperm, a whole mom-method of obtaining a sex-adjusted calf of about $70 \%$ without decreasing the pregnancy rate and increasing or decreasing the duration of pregnancy, It is expected to play a very important role in production.

\section{CONFLICTS OF INTEREST}

No potential conflict of interest relevant to this article was reported.

\section{ORCID}

Enkhbolor Barsuren: https://orcid.org/0000-0001-7592-8047 Sang Hwan Kim: https://orcid.org/0000-0003-0996-6912 Ho-Jun Lee: https://orcid.org/0000-0002-5872-8075

Jong Taek Yoon: https://orcid.org/0000-0002-9408-8239

\section{REFERENCES}

Baruselli PS, de Sá Filho MF, Martins CM, Nasser LF, Nogueira MF, Barros CM, Bó GA. 2006. Superovulation and embryo transfer in Bos indicus cattle. Theriogenology. 7;65(1):77-88.

Block J, Bonilla L, Hansen PJ. 2010. Efficacy of in vitro embryo transfer in lactating dairy cows using fresh or vitrified embryos produced in a novel embryo culture medium. J Dairy Sci. 93(11):5234-42.

Carvalho JO, Sartori R, Machado GM, Mourão GB, Dode MA.
2010. Quality assessment of bovine cryopreserved sperm after sexing by flow cytometry and their use in in vitro embryo production. Theriogenology. 74(9):1521-30.

De Vries A, Feleke S. 2008. Prediction of future uniform milk prices in Florida federal milk marketing order 6 from milk futures markets. J Dairy Sci. 91(12):4871-80.

DeJ Tubman, LM arnette JM, Nebel RL, Marshall CE. 2009. Evaluating the success of sex-sorted semen in US dairy herds from on farm records. Theriogenology. 1;71(1):49-58.

DeJarnette JM, Nebel RL, Marshall EC. 2009. Evaluating the success of sex-sorted semen in US dairy herds from on farm records. Theriogenology. 71:49-58.

Dell'Aqua Jr JA, Papa FO, Araújo Jr JP, Freitas CP, Ponchirolli CB, Figueiredo AS. 2006. Aplicação do sêmensexadonaprodução de embriões. Acta Sci Vet. 34(Suppl 1):205-12.

Fisher LJ, Williams CJ. 1978. Effect of environmental factors and fetal and maternal genotype on gestation length and birth weight of Holstein calves. J Dairy Sci. 61(10):1462-7.

Hansen PJ. 2004. Physiological and cellular adaptations of zebu cattle to thermal stress. AnimReprod Sci. 82-83:349-60.

Hansen PJ. 2007. Exploitation of genetic and physiological determinants of embryonic resistance to elevated temperature to improve embryonic survival in dairy cattle during heat stress. Theriogenology. 1;68(Suppl 1):S242-9.

Hayakawa H, Hirai T, Takimoto A, Ideta A, Aoyagi Y. 2009. Superovulation and embryo transfer in Holstein cattle using sexed sperm. Theriogenology. 1;71(1):68-73.

Hidalgo CO, Gómez E, Prieto L, Duque P, Goyache F, Fernández L, Fernández I, Facal N, Díez C. 2004. Pregnancy rates and metabolic profiles in cattle treated with propylene glycol prior to embryo transfer. Theriogenology. 62(3-4):664-76.

Hossein-Zadeh NG. 2010. Evaluation of the genetic trend of milk yield in the multiple ovulation and embryo transfer populations of dairy cows, using stochastic simulation. C R Biol. 333(10):710-5.

Larson JE, Lamb GC, Funnell BJ, Bird S, Martins A, Rodgers JC. 2010. Embryo production in superovulated Angus cows inseminated four times with sexed-sorted or conventional, frozen-thawed semen. Theriogenology. 15;73(5):698-703.

Norman HD, Hutchison JL, Miller RH. 2010. Use of sexed semen and its effect on conception rate after ET, calf sex, dystocia, and stillbirth of Holsteins in the United States. J Dairy Sci. 93(8):3880-90.

Norman HD, Wright JR, Kuhn MT, Hubbard SM, Cole JB, VanRaden PM. 2009. Genetic and environmental factors that affect gestation length in dairy cattle. J Dairy Sci. 92(5):225969.

Peippo J, Vartia K, Kananen-Anttila K, Räty M, Korhonen K, Hurme T, Myllymäki H, Sairanen A, Mäki-Tanila A. 2009. Embryo production from superovulated Holstein-Friesian dairy heifers and cows after insemination with frozenthawed sex-sorted X spermatozoa or unsorted semen. AnimReprod Sci. 111(1):80-92.

Rath D, Johnson LA. 2008. Application and commercialization of flow cytometrically sex-sorted semen. ReprodDomest 
Anim. Suppl 2:338-46.

Reik W. 2007. Stability and flexibility of epigenetic gene regulation in mammalian development. Nature. 24;447(7143):42532.

Reik W, Walter J. 2001. Evolution of imprinting mechanisms: the battle of the sexes begins in the zygote. Nat Genet. 27(3):255-6.

Sá Filho MF, Carvalho NA, Gimenes LU, Torres-Júnior JR, Nasser LF, Tonhati H, Garcia JM, Gasparrini B, Zicarelli L, Baruselli PS. 2009. Effect of recombinant bovine somatotropin (bST) on follicular population and on in vitro buffalo embryo production. AnimReprod Sci. 113(1-4):51-9.

Seidel GE Jr. 2003. Sexing mammalian sperm--intertwining of commerce, technology, and biology. AnimReprod Sci. 15;79(3-4):145-56.

Seidel GE Jr, Schenk JL. 2008. Pregnancy rates in cattle with cryopreserved sexed sperm: effects of sperm numbers per inseminate and site of sperm deposition. AnimReprod Sci. 105(1-2):129-38.

Stewart BM, Block J, Morelli P, Navarette AE, Amstalden M, Bonilla L, Hansen PJ, Bilby TR. 2011. Efficacy of embryo transfer in lactating dairy cows during summer using fresh or vitrified embryos produced in vitro with sex-sorted semen. J Dairy Sci. 94(7):3437-45.

Tubman LM, Brink Z, Suh TK, Seidel GE Jr. 2004. Characteristics of calves produced with sperm sexed by flow cytometry/ cell sorting. J Anim Sci. 82(4):1029-36.

Underwood SL, Bathgate R, Pereira DC, Castro A, Thomson PC, Maxwell WM, Evans G. 2010. Embryo production after in vitro fertilization with frozen-thawed, sex-sorted, re-frozenthawed bull sperm. Theriogenology. 73(1):97-102. 